\title{
LENGTH-FREQUENCY COMPOSITIONS AND WEIGHT-LENGTH RELATIONS FOR BIG- EYE TUNA, YELLOWFIN TUNA, AND ALBACORE (PERCIFORMES: SCOMBRINAE) IN THE ATLANTIC, INDIAN, AND EASTERN PACIFIC OCEANS
}

\author{
Guoping $Z H U^{1,2,3}$, Liuxiong $X U^{1,2 *}$, Yingqi $Z H O U^{1,2}$, and Xiaojie $D A I^{1,2,3}$ \\ ${ }^{1}$ The Key Laboratory of Shanghai Education Commission for Oceanic Fisheries Resources Exploitation, \\ College of Marine Sciences, Shanghai Ocean University, Shanghai 201306, China \\ ${ }^{2}$ The Key Laboratory of Sustainable Exploitation of Oceanic Fisheries Resources (Shanghai Ocean University), \\ Ministry of Education, Shanghai 201306, China \\ ${ }^{3}$ Tuna Fishery Technical Working Group of China, Shanghai 201306, China
}

\begin{abstract}
Zhu G., Xu L., Zhou Y., Dai X. 2008. Length-frequency compositions and weight-length relations for bigeye tuna, yellowfin tuna, and albacore (Perciformes: Scombrinae) in the Atlantic, Indian, and eastern Pacific oceans. Acta Ichthyol. Piscat. 38 (2): 157-161.
\end{abstract}

Background. Bigeye tuna, Thunnus obesus (Lowe, 1839); yellowfin tuna, Thunnus albacares (Bonnaterre, 1788); and albacore, Thunnus alalunga (Bonnaterre, 1788), are very important species for world fisheries. It is crucial to the future existence of those economically important species that the best possible biological data on the species is provided to fisheries managers.

Materials and Methods. The weight-length relations (WLRs) for bigeye tuna, yellowfin tuna, and albacore, collected in the Atlantic, Indian, and eastern Pacific oceans were studied using commonly accepted methodology.

Results. Significant differences can be found from the fork length distributions and the WLRs of the above 3 tuna species and the relations of gilled-gutted and whole weight of bigeye and yellowfin tunas collected from the Atlantic, Indian, and Eastern Pacific Oceans. Significant differences of fork length distributions can be found for bigeye tuna, yellowfin tuna, and albacore from the three areas. The growth exponents $(b)$ of bigeye tuna, yellowfin tuna, and albacore collected from the Atlantic, Indian, and eastern Pacific oceans register significant deviations from isometric value of 3 .

Conclusion. The date collected will be useful for the fisheries management of the three species studied.

Keywords: bigeye tuna, yellowfin tuna, albacore, weight-length relation, Thunnus

\section{INTRODUCTION}

The weight-length relation (WLR) is an important tool in fish biology, physiology, ecology, and fisheries assessment and has been originally used to provide information on the condition of fish and determine whether somatic growth is isometric or allometric (Ricker 1975, Oscoz et al. 2005). WLRs are useful in determining weight and biomass when only length measurements are available, as indications of condition and to allow for comparisons of species growth between different regions (Koutrakis and Tsikliras 2003).

Bigeye tuna, Thunnus obesus (Lowe, 1839); yellowfin tuna, Thunnus albacares (Bonnaterre, 1788); and albacore, Thunnus alalunga (Bonnaterre, 1788), are the important commercial species in the tropical and subtropical waters of the Atlantic, Indian, and Pacific oceans (Driggers et al. 1999, Sun et al. 2001, Miao and Huang 2003, Farley et al. 2006). It constitutes an extremely valuable fishery resource intensively exploited by Asian longliners, and US and European purse seiners, at various stages of its life cycle (Stéquert and Conand 2000). However, the stocks of the above tuna species, especially bigeye tuna, are almost on the verge of over-exploitation and may soon be regarded as overfished (Joseph 2003). It is crucial to the future existence of this economically important species that the best possible biological data on the species is provided to fisheries managers (Manooch and Hinkley 1991). This study contributes to the knowledge of the WLRs of bigeye tuna, yellowfin tuna and albacore of the Atlantic, Indian, and Pacific Oceans.

\footnotetext{
* Correspondence: Professor Liuxiong XU, Dean, College of Marine Sciences, Shanghai Ocean University, 999 Huchenghuan Road, Lingang New City, Shanghai 201306, China, phone: 86-21-61900301, e-mail: lxxu@shou.edu.cn
} 


\section{MATERIALS AND METHODS}

Study area and data sampling. Specimens were caught using longline and randomly sampled on board the Chinese longline vessels operating in the Atlantic (from October 2002 to April 2006), Indian (from January 2003 to December 2005), and Eastern Pacific (from July 2003 to November 2006) Oceans (Fig. 1) on a daily basis. For each sampled fish, fork length (FL) was measured to the nearest $1 \mathrm{~cm}$ and grouped in $5 \mathrm{~cm}$ fork length classes. Whole weight (RW) and gilled-gutted weight (DW) were measured with electronic platform balances to the nearest $1 \mathrm{~g}$. showed that significant differences of the relations of gilled-gutted and whole weight could be found among areas for bigeye tuna $(F=173.4808, d f=3555, P<0.001)$ and yellowfin tuna $(F=5.3132, d f=1370, P<0.001)$.

The details of weight-length relations of bigeye-, yellowfin tuna, and albacore from the Atlantic, Indian, and eastern Pacific oceans were given in Table 1. The values of the parameter $b$ were well within the normal range of 2.5 to 3.5 (Carlander 1969) and the range given by Tesch (1971) (between 2 and 4). Carlander (1977) indicated that values of $b<2.5$ or $>3.5$ are often derived from samples

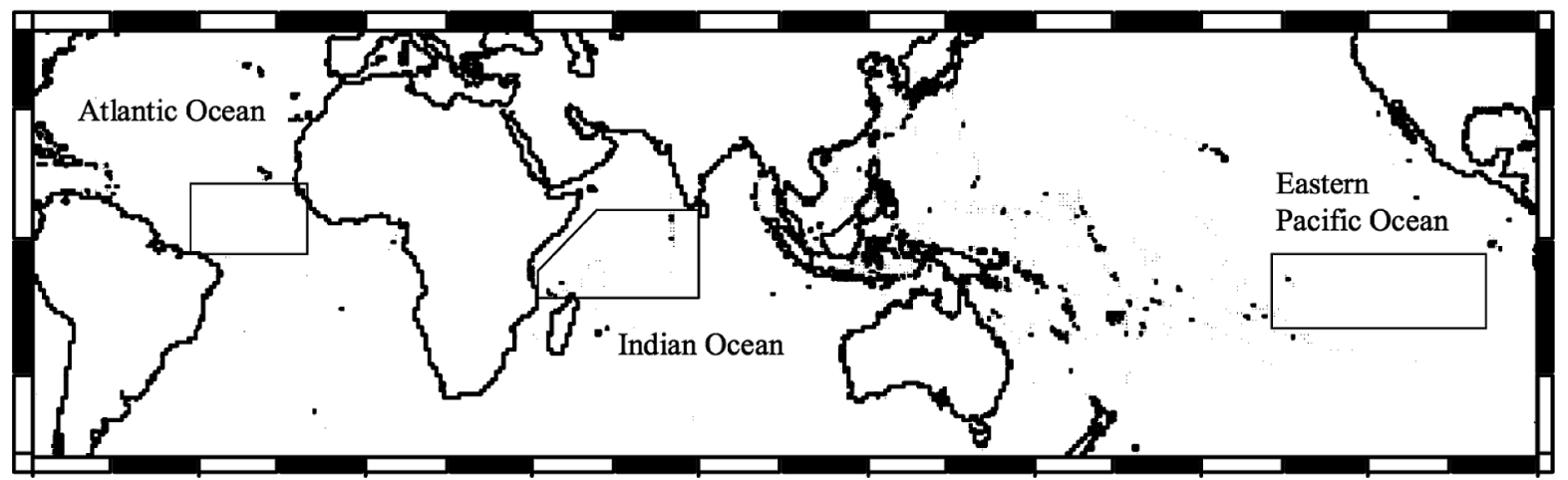

Fig. 1. Map of the areas studied

Length-weight relations. The differences of FL distribution of tuna species among areas were tested by Kruskal-Wallis one-way analysis of variance (K-W test).

The length-weight relations was quantified with an exponential regression equation

$$
W=a L^{b} e^{\varepsilon}, \varepsilon \sim \mathrm{N}\left(0, \sigma^{2}\right),
$$

where: $W$ was the gilled-gutted weight (DW) or the whole weight (RW) [g],

$L$ the fork length (FL) [cm], $b$ the growth exponent or length-weight factor, and $a$ was a constant. The parameters $(a$ and $b)$, the coefficient of determination $\left(r^{2}\right)$ and the 95\% confidence limits (CL) were estimated over the entire period by least squares regression using the log transformed weights and sizes.

The WLRs were tested for significant difference among areas by means of analysis of covariance (ANCOVA). In order to confirm whether $b$-values obtained in the linear regressions were significantly different from the isometric value (3), Student's $t$-test $\left(H_{0}: b=3\right)$ was applied (Sokal and Rohlf 1987).

\section{RESULTS AND DISCUSSIONS}

The FL range and mean FL of bigeye-, yellowfin tuna, and albacore from the Atlantic, Indian, and eastern Pacific oceans were given in Table 1 . The $\mathrm{K}-\mathrm{W}$ test showed that significant differences of FL distributions could be found for bigeye tuna $(H=80.7991, P<0.001)$, yellowfin tuna $(H=181.2648, P<0.001)$ and albacore $(H=77.3503$, $P<0.001$ ) from the three areas (Fig. 2).

The relations between gilled-gutted weight and whole weight were showed in Table 2. The ANCOVA analysis with narrow size ranges, so narrow size range $(93.0-119 \mathrm{~cm})$ and limited samples (88) may be contributed to the reason why $b$ value $=2.343(<2.5)$ was low for albacore in the Indian Ocean. The results of Student's $t$-test showed that regression coefficients of bigeye tuna, yellowfin tuna, and albacore collected from the Atlantic, Indian, and eastern Pacific oceans register significant deviations from isometric value of 3 (Table 1). The Student's $t$-test also shows that $b$ values of bigeye tuna among the Atlantic, Indian, and eastern Pacific oceans show no significant differences, and the similar results can be found for yellowfin tuna and albacore. However, with the limited size ranges or the number of samples, particularly albacore, in the present study, further works should be done for comparing the differences of $b$ values of bigeye tuna, yellowfin tuna, and albacore among the Atlantic, Indian, and eastern Pacific oceans, such as the differences in condition between small and large individuals in the respective area at that point in time and more WLR estimates should be considered (Froese 2006). The ANCOVA analysis shows that significant differences of the WLRs can be found among the Atlantic, Indian and Eastern Pacific Oceans for bigeye tuna $(F=334.4317, d f=5216, P<0.001)$, yellowfin tuna $(F=141.4433, d f=1850, P<0.001)$, and albacore $(F=66.7288, d f=329, P<0.001)$, respectively.

Longline fishery targets larger albacore, bigeye-, and yellowfin tuna, however, purse seiners take a small, but significant, by-catch of bigeye tuna (Hampton 2006). Tantivala (2000) set up the length-weight relation of $D W=0.082 F L^{2.6480}\left(r^{2}=0.99, n=232\right)$ for the juvenile bigeye tuna $(30-82 \mathrm{~cm})$ and $D W=0.031 F L^{2.8580}\left(r^{2}=0.97\right.$, $n=368)$ for the juvenile yellowfin tuna $(28-84 \mathrm{~cm})$ collected from purse seine in the eastern Indian Ocean. Due 

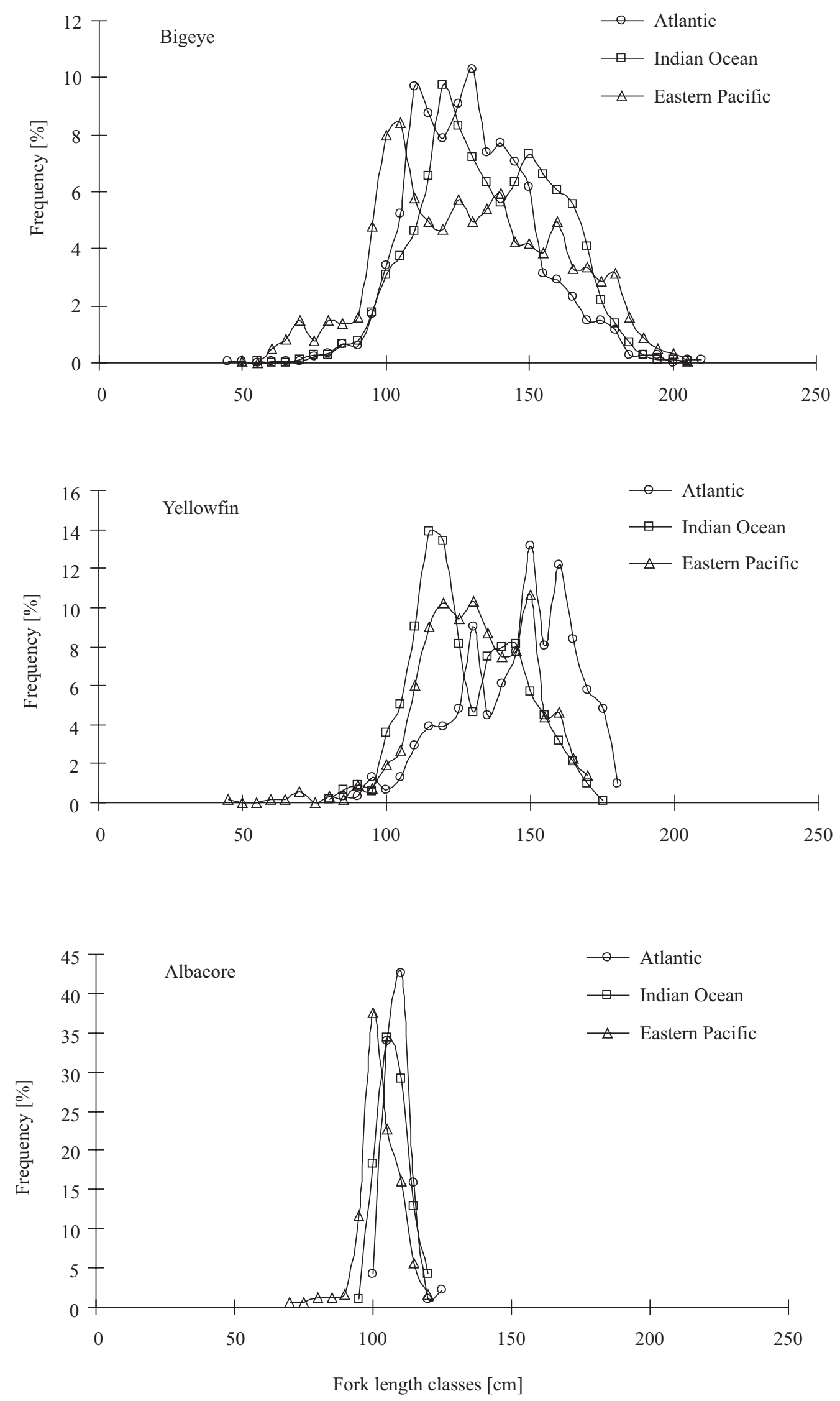

Fig. 2. The fork length distributions of bigeye tuna, yellowfin tuna, and albacore collected from the Atlantic, Indian, and eastern Pacific oceans 
Descriptive statistics and Length-weight relation parameters for bigeye tuna, yellowfin tuna, and albacore from the Atlantic, Indian, and eastern Pacific oceans

\begin{tabular}{|c|c|c|c|c|c|c|c|c|c|c|c|}
\hline \multirow{2}{*}{ Species } & \multirow{2}{*}{ Area } & \multirow{2}{*}{$\begin{array}{c}F L \text { range } \\
{[\mathrm{m}]}\end{array}$} & \multirow{2}{*}{$\begin{array}{c}\text { Mean FL } \\
{[\mathrm{cm}]}\end{array}$} & \multirow{2}{*}{$\begin{array}{c}\text { Mean } W \\
{[\mathrm{~g}]}\end{array}$} & \multirow{2}{*}{$n$} & \multirow{2}{*}{$a$} & \multirow{2}{*}{$b$} & \multirow{2}{*}{$95 \%$ CL of $b$} & \multirow{2}{*}{$r^{2}$} & \multicolumn{2}{|c|}{$t$-test $\left(H_{0}: b=3\right)$} \\
\hline & & & & & & & & & & $t$ value & $P$ value \\
\hline BET & Atlantic & $43.2-206.0$ & 128.0 & 36546.2 & 2280 & 0.0158 & 2.997 & $2.968-3.026$ & 0.9471 & 9.837 & $<0.001$ \\
\hline YFT & Atlantic & $83.0-176.8$ & 143.2 & 45309.0 & 299 & 0.0166 & 2.969 & $2.884-3.054$ & 0.9412 & 12.411 & $<0.001$ \\
\hline ALB & Atlantic & $99.1-125.0$ & 107.2 & $23985.1 *$ & 94 & $0.0438 *$ & $2.825^{*}$ & $2.499-3.151$ & 0.7628 & 10.338 & $<0.001$ \\
\hline BET & Indian Ocean & $54.8-201.0$ & 134.0 & 45195.7 & 1052 & 0.0247 & 2.926 & $2.898-2.954$ & 0.9649 & 199.492 & $<0.001$ \\
\hline YFT & Indian Ocean & $78.0-171.0$ & 125.9 & 32267.9 & 1033 & 0.0163 & 2.985 & $2.953-3.017$ & 0.9696 & 29.149 & $<0.001$ \\
\hline ALB & Indian Ocean & $93.0-119.0$ & 105.7 & 24045.5 & 88 & 0.434 & 2.343 & $2.066-2.620$ & 0.7644 & 44.196 & $<0.001$ \\
\hline BET & Eastern Pacific & $60.0-202.0$ & 127.3 & 41723.5 & 1436 & 0.0132 & 3.043 & $1.841-3.728$ & 0.9742 & 123.717 & $<0.001$ \\
\hline YFT & Eastern Pacific & $93.0-170.0$ & 129.5 & 33211.5 & 520 & 0.00418 & 3.244 & $3.176-3.312$ & 0.9449 & 161.705 & $<0.001$ \\
\hline ALB & Eastern Pacific & $70.0-118.0$ & 100.7 & 18846.9 & 147 & 0.0542 & 2.760 & $2.552-2.968$ & 0.8256 & 27.609 & $<0.001$ \\
\hline
\end{tabular}

* Weight is whole weight [g]; BET = bigeye tuna; YFT = yellowfin tuna; ALB = albacore; $n$ : sample size; FL: fork length [cm]; $W$ : gilled-gutted weight [g]; CL = confidence limit; $a=$ the parameter in the $W-L$ relation; $b=$ slope; $r^{2}=$ coefficient of determination.

Table 2

Descriptive statistics and the parameters in the relation between gilled-gutted weight and whole weight for bigeye- and yellowfin tunas from the Atlantic, Indian, and eastern Pacific oceans

\begin{tabular}{lcccrc}
\hline Species & Area & Slope (SE) & Intercept (SE) & \multicolumn{1}{c}{$n$} & $r^{2}$ \\
\hline Bigeye tuna & Atlantic & $1.146(0.002)$ & $1.557(0.077)$ & 1180 & 0.9956 \\
Yellowfin tuna & Atlantic & $1.084(0.004)$ & $2.439(0.169)$ & 299 & 0.9969 \\
Bigeye tuna & Indian Ocean & $1.128(0.005)$ & $1.254(0.241)$ & 1177 & 0.9812 \\
Yellowfin tuna & Indian Ocean & $1.149(0.003)$ & $0.087(0.088)$ & 881 & 0.9959 \\
Bigeye tuna & Eastern Pacific & $1.085(0.009)$ & $2.784(0.480)$ & 580 & 0.9906 \\
Yellowfin tuna & Eastern Pacific & $1.097(0.008)$ & $1.817(0.313)$ & 192 & 0.9895 \\
\hline
\end{tabular}

$\mathrm{SE}=$ standard error; $n=$ sample size; $r^{2}=$ coefficient of determination.

to the fishing gear size selectivity, most samples in the present study do not include juveniles or very small individuals (such as albacore). In this context, and according to Petrakis and Stergiou (1995), the use of these WLRs should be rigorously limited to the size ranges applied in the estimation of the linear regression parameters. For this reason, it is particularly dangerous to extrapolate data to fish larvae (Pepin 1995), juveniles (Safran 1992), or immature stages (Bagenal and Tesch 1978).

The WLR in fishes is affected by a number of factors including season, habitat, food availability, feeding rate, gonad development, sex, spawning period, health, preservation techniques, and locality (Tesch 1971, Bagenal and Tesch 1978, Froese 2006); and these factors were not considered in the present study. However, unlike the parameter $a$, which may vary daily, seasonally, and/or between different habitats, the parameter $b$ is characteristic of the species (Mayrat 1970) and generally does not vary significantly throughout the year (Bagenal and Tesch 1978).

\section{ACKNOWLEDGEMENTS}

The authors are grateful to the Chinese scientific fishery observers aboard China longline vessels who collected samples. The journal editor and two anonymous reviewers provided useful technical and editorial advice. The present study is sponsored by Shanghai (China) Leading Academic Project grant No. S30702, Special Science and Technology Research Funds for Shanghai Universities and Colleges to Select and Foster Excellent Young Teachers grant No. B-8101-08-0022, Innovation Program of Shanghai Municipal Education Commission grant No. 09YZ275 and Initial Doctoral Funding of Shanghai Ocean University grant No. B-8202-07-0279.

\section{REFERENCES}

Bagenal T.B., Tesch F.W. 1978. Age and growth. Pp. 101-136. In: Bagenal T. (ed.) Methods for assessment of fish production in freshwaters. IBP handbook No. 3. Blackwell Scientific Publications, Oxford, UK.

Carlander K.D. 1969. Handbook of freshwater fishery biology. Vol. 1. The Iowa State University Press, Ames, IA.

Carlander K.D. 1977. Handbook of freshwater fishery biology, Vol. 2. The Iowa State University Press, Ames, IA. 431 pp.

Driggers W.B. III, Grego J.M., Dean J.M. 1999. Age and growth of yellowfin tuna (Thunnus albacares) in the western north Atlantic Ocean. Collective Volume of Scientific Papers ICCAT 123: 374-383.

Farley J.H., Clear N.P., Leroy B., Davis T.L.O., McPherson G. 2006. Age, growth and preliminary estimates of maturity of 
bigeye tuna, Thunnus obesus, in the Australian region. Marine and Freshwater Research 57: 713-724.

Froese R. 2006. Cube law, condition factor and weight-length relationships: history, meta-analysis and recommendations. Journal of Apply Ichthyology 22: 241-253.

Hampton J. 2006. Estimates of large-scale purse seine and longline fishing capacity in the western and central Pacific Ocean based on stock assessments of target species. Methodological Workshop on the Management of Tuna Fishing Capacity. La Jolla, CA, May 8-12, 2006. ftp://ftp.fao.org/docrep/fao/010/a1338e/a1338e06.pdf

Joseph J. 2003. Managing fishing capacity of the world tuna fleet. FAO Fisheries Circular No. 982. http://www.fao.org/docrep/ /005/y4499e/y4499e00.htm\#Contents.

Koutrakis E.T., Tsikliras A.C. 2003. Length-weight relationships of fishes from three northern Aegean estuarine systems (Greece). Journal of Apply Ichthyology 19: 258-260.

Manooch C.S. III, Hinkley J.A. 1991. Preliminary age study of yellowfin tuna collected from the Equatorial Eastern Atlantic. Collective Volume of Scientific Papers ICCAT 36: 515-522.

Mayrat A. 1970. Allométrie et taxinomie. Revue de Statistique Appliquée 18: 47-58.

Miao Z.Q., Huang X.C. 2003. [Distant water tuna fishery]. Shanghai Science and Technology Press, Shanghai. [In Chinese.]

Oscoz J., Campos F., Escala M.C. 2005. Weight-length relationships of some fish species of the Iberian Peninsula. Journal of Applied Ichthyology 21: 73-74.

Pepin P. 1995. An analysis of the length-weight relationships of larval fish: limitations of the general allometric model. Fishery Bulletin 93: 419-426.
Petrakis G., Stergiou K.I. 1995. Weight-length relationships for 33 fish species in Greek waters. Fisheries Research 21: 465-469.

Ricker W.E. 1975. Computation and interpretation of biological statistics of fish population. Bulletin of the Fisheries Research Board of Canada 191: 1-382.

Safran P. 1992. Theoretical analysis of the weight-length relationship in fish juvenile. Marine Biology 112: 545-551.

Sokal R.R., Rohlf F.J. 1987. Introduction to biostatistics. 2nd edn. Freeman, New York.

Stéquert B., Conand F. 2000. Preliminary studies of age and growth of bigeye tuna (Thunnus obesus) in the western Indian Ocean. Indian Ocean Tuna Commission Proceedings 3: 249-255.

Sun C.L., Huang C.L., Yeh S.Z. 2001. Age and growth of the bigeye tuna, Thunnus obesus, in the western Pacific Ocean. Fishery Bulletin 99: 502-509.

Tantivala C. 2000. Some biological study of Yellowfin Tuna (Thunnus albacares) and Bigeye Tuna (Thunnus obesus) in the Eastern Indian Ocean. Indian Ocean Tuna Commission Proceedings 3: 436-440.

Tesch F.W. 1971. Age and growth. Pp. 99-130. In: Ricker E. (ed.). Methods for assessment of fish production in fresh waters. Blackwell Scientific Publications, Oxford, UK.

Received: 28 August 2008

Accepted: 26 November 2008 Published electronically: 15 December 2008 